\title{
Death of a secular saint
}

Moscow's mourning of the death of Sakharov is understandable, but Sakharov's life has touched all of us in ways that the international research community dares not forget.

IN other times and places, Andrei Dmietrievich Sakharov, who died last week, would have been made a saint. For the past quarter of a century in the Soviet Union, he lived as one. Since his return from exile in Gorky in 1986, the high and mighty have trudged to the tiny kitchen of his Moscow apartment, seeking enlightenment and a little courage. Like the classical saints, Sakharov taught by example, often breathtaking example.

Although all of us everywhere are now in Sakharov's debt, Mr Mikhail Gorbachev is the most conspicuous beneficiary of his turbulent career. The scandalous decision to exile Sakharov was a bankrupt administration's attempt to silence the most distinguished critic of its way of doing business with the courage to speak his mind within the Soviet Union. Exile would have served its purpose if Sakharov had been more easily cowed. In the event, his fortitude during these six years, and his puckish ingenuity in arranging that his opinions continued to circulate, eventually helped to force the election of a reformer as generalsecretary of the Soviet Communist Party and then made possible the goal of perestroika on which Gorbachev has set his sights. Although Sakharov, pushing for faster change, has latterly been a thorn in his leader's side, Gorbachev did well to acknowledge his debt on Monday morning.

Sakharov's wider contribution to the new temper of Soviet life is the example of his disarming and, often, infuriating directness. His habit was to say what he believed, about personal liberty, nuclear weapons or even the dilemma of Nagorno Karabakh, without calculating in advance what his listeners would think of him for his opinions. Much of the turbulent Congress of People's Deputies now in session has taken its cue from Sakharov. The benefit is that the Soviet people now know how desperate is their plight.

The rest of us have a more subtle debt to pay, arising from Sakharov's sense of professional rectitude. Sakharov was conscripted into military research during the Second World War and, by 1945, had become one of the small group of theoreticians canvassing the feasibility of both the peaceful and the military uses of thermonuclear fusion. As the world

\section{Page numbers: Vol. 342}

LIBRARIANS please note: A production problem caused a discontinuity between the end of the 30 November issue (page 578) and the start of the 7 December issue (page 599). The 'missing' pages, 579-598, have not been allotted. knows, the military project was carried through successfully, and Sakharov rewarded with the Order of Lenin (snatched away again when he was exiled). But, from the outset, Sakharov insisted on the dangers inherent in this enterprise. During his own exile to Gorky, he pleaded publicly the cases of others whose plight was even worse, urging that the international community of scientists, "the one real worldwide community that exists today", should shoulder the responsibilities its privileges imply (Nature 291, $184 ; 1981)$. How well will the responsibility be discharged now that the prophet is dead?

\section{Leaders lead, OK?}

With Sakharov gone, Mr Mikhail Gorbachev will have to change his style.

How should Mr Gorbachev comport himself in the interval between now and the time when there is another gadfly to turn attention from his own subversiveness? He himself must fill the vacuum left by Sakharov. But how?

On one cogent view, perestroika has already run into the ground: there is nothing in the shops. At a more abstract level, the rouble is overvalued, meaning that there will have to be a real (not a fake) devaluation in the next few months. People will have to pay more for luxuries, of which they have precious few as things are. Then there may be room for a true price reform, from which even Gorbachev has so far shrunk for fear of the trouble it will cause. Between now and a year from now, Gorbachev has to resolve the economic crisis. So far, luck has been on his side.

The truth, much more encouraging, is that time is also on Gorbachev's side, if only in a narrow sense. So much is apparent from the past few weeks, but here is how that logic goes. Who would have thought, just a few weeks back, that the Soviet enterprise required a new regime in East Germany? Now there is such a one, and also in Czechoslovakia. At this rate, it will be Romania next, or even Albania. For the time being, Gorbachev cannot but be pleased; people, it appears, are on the side of change. But how quickly will change be allowed to happen? Not particularly quickly, it appears. In the short run, Gorbachev will have to face the greater difficulty of saying where he stands. Without Sakharov, that will not be easy. 